International Research Journal of Management, IT \& Social Sciences
Available online at https://sloap.org/journals/index.php/irjmis/
Vol. 8 No. 6, November 2021, pages: 679-689
$\begin{aligned} & \text { ISSN: 2395-7492 } \\ & \text { https://doi.org/10.21744/irjmis.v8n6.1979 }\end{aligned}$

\title{
Management as a Necessary Tool for the Prevention of Violence Against Women
}

\begin{tabular}{|c|c|}
\hline & $\begin{array}{r}\text { Meglis Rivero Favier } \\
\text { Nayra Martínez Manzanares } \\
\text { Karla Mercedes Mendoza Loor } \\
\text { Telly Yarita Macías Zambrano }\end{array}$ \\
\hline Article history: & Abstract \\
\hline $\begin{array}{l}\text { Submitted: } 27 \text { September } 2021 \\
\text { Revised: } 18 \text { October } 2021 \\
\text { Accepted: } 09 \text { November } 2021\end{array}$ & \multirow{3}{*}{$\begin{array}{l}\text { The chair "Women, family and Guantanamo society" in the Guantánamo } \\
\text { province as part of its functions intends the following investigation that } \\
\text { addresses the theme of the prevention of violence against women from its } \\
\text { management. This has the purpose of contributing to the educational } \\
\text { preparation of agencies and social agents as an effective response to the } \\
\text { demands of today's Cuban society. The study assumes the methodological- } \\
\text { materialist and historical dialectical conception with the use of general } \\
\text { research methods, with references, aspects of historical and theoretical- } \\
\text { methodological evolution in the sociological, psychological, pedagogical and } \\
\text { legal areas. The diagnostic results of the study made it possible to design as a } \\
\text { methodological proposal a management strategy for the prevention of violence } \\
\text { against women, which is strengthened from the integration of agencies and } \\
\text { social agents, which places the University as the most important educational } \\
\text { agency of the community. } \\
\text { International research journal of management, IT and social sciences } \odot \text { C 2021. } \\
\text { This is an open access article under the CC BY-NC-ND license } \\
\text { (https://creativecommons.org/licenses/by-nc-nd/4.0/). }\end{array}$} \\
\hline $\begin{array}{l}\text { Keywords: } \\
\text { educational; } \\
\text { management; } \\
\text { necessary tool; } \\
\text { strategy; } \\
\text { violence against women; }\end{array}$ & \\
\hline & \\
\hline \multicolumn{2}{|c|}{$\begin{array}{l}\text { Corresponding author: } \\
\text { Meglis Rivero Favier, } \\
\text { University of Guantánamo, Guantánamo, Cuba. } \\
\text { Email address: mriverofavier@gmail.com }\end{array}$} \\
\hline
\end{tabular}

Universidad de Guantánamo, Guantánamo, Cuba

Universidad de Guantánamo, Guantánamo, Cuba

Instituto Superior Tecnológico Paulo Emilio Macías, Portoviejo, Manabí, Ecuador

Instituto Superior Tecnológico Paulo Emilio Macías, Portoviejo, Manabí, Ecuador 


\section{Introduction}

The university has the duty to transform itself within to respond to the social demands of the society in which it is inserted. According to Horruitiner Silva (2006), the exclusivity of universities is weighed as institutions that generate superior knowledge, which promote behaviors in accordance with that level of preparation, which must be for life and for society. This, at the same time that it trains the new generations, are scientific research institutions of the highest level Horruitiner Silva (2006), an idea materialized since the triumph of the Revolution, carrying out a set of social transformations based on new concepts of equity and social justice. As ways to materialize these precepts, together with the Federation of Cuban Women, the Chairs for women in the Universities are created, in order to insert the gender approach in teaching, research and university extension, in correspondence with the university functions, so your work should be joint (Kourilsky \& Walstad, 1998; Fraser et al., 1987).

Given this, it is essential to recognize the joint work carried out by the agencies and social agents with the support of the universities, in order to prevent violence against women; but it is also valid to recognize the shortcomings that are evident in the theoretical-methodological order in this working group. In this research, the management of the Chair "Woman, Family and Guantanamera Society" stands out at the university, as a vital educational agency for the methodological preparation of agencies and social agents in terms of the prevention of violence against women. There are countries that have been investigating these difficulties at the time of the pandemic, in Ecuador in studies carried out these cases have increased there are statistics related to it Navarrete et al. (2020), in the period of time of the quarantine, s women were they are at risk of domestic violence (McGill et al., 1992; Broadbent \& Laughlin, 2009).

In Cuba, the studies carried out on violence against women are distinguished by being distributed in a dispersed manner in localities of the country, mainly in the western region and focused according to the profiles carried out by the investigations, such as: criminology, legal sciences , medical, psychological and social (Sihabudin, 2017; Seethanaik, 2015). In the province of Guantánamo, it is considered that the investigations carried out are still scarce and isolated, although with a high level of impact and professionalism in the results. Among the main researchers, Dr. and Specialist in Legal Medicine Sandra Toirac $(1998,2006)$ stands out, a pioneer in research on the subject with important studies, with relevance for the description and characterization of the behavior of the manifestations and injuries of the victims of the violence and the acts themselves. In the order of Social Sciences, Santisteban \& Egues (2014), stands out, who directs his studies to the role of the school in the prevention of intrafamily violence; who addresses in her research the preparation of doctors in the care of adolescents who have been violated and the author of this research (2012) who performs a characterization of the main manifestations of gender violence in Guantanamo (Sandberg \& Hofer, 1987; Evenson \& Westphal, 1995).

It is necessary to state that most of the investigations are framed in the characterization and understanding of the phenomenon, which has to do to a great extent, with the lack of for the concretion of actions that are proposed in a unilateral way and without the adequate preparation of agencies. and agents and social. Given this, it is essential to recognize the joint work carried out by the agencies and social agents with the support of the universities, in order to prevent violence against women; but it is also valid to recognize the shortcomings that are evident in the theoreticalmethodological order in this working group (Mujeres, 2015; Proveyer, 2014; Martínez et al., 2012). Consequently, in this research, an important potential stands out in the university, which from the work of the Chair "Woman, family and Guantanamo society" as a vital educational agency. It takes into account its potential for knowledge management, as well as providing the necessary theoretical-methodological tools for the prevention of violence against women. Hence, there is evidence of limited management of the Chair "Women, family and Guantanamo society" in the interaction and involvement of the educational agencies and agents of the university, in the prevention of violence against women. It is also worth considering the little theoretical-methodological preparation of the agencies and social agents for the prevention of violence against women, from the community whose social responsibility is their confrontation (Hurlbert \& Gupta, 2015; Kultima et al., 2011). All the foregoing made it possible to determine the following shortcomings:

1. Insufficient theoretical-methodological preparation of the different social agents and agencies for the prevention of violence against women.

2. Little interrelation between the educational actions carried out by the different social institutions for the prevention of violence against women.

3. Limited extension management of the Chair "Guantanamo Women, Family and Society" with agencies and social agents for the prevention of violence against women. 
In this order, the objective of this research is: to develop a management strategy "for the prevention of violence against women based on the work of the Chair" Guantanamo women, family, and society.

\section{Materials and Methods}

For the study diagnosis, a total of 27 agencies and social agents were selected as a sample. Composed of the Provincial Center of Legal Medicine, the provincial delegation Federation of Cuban women, House of Orientation to women and the family of the municipality of Guantánamo, the provincial Prosecutor's Office, the First Unit of the National Revolutionary Police in the province of Guantánamo, 4 family medical offices, the Sociocultural Project "El Garaje", 5 doctors from the Guard Corps service of the General Teaching Hospital, 11 social workers (Toirac Perera et al., 1998; Lima, 2012). From a qualitative perspective and as a consequence of the categorization process, the category of this study was determined as prevention of violence against women: a set of integrated educational actions, anticipatory, retroactive and bidirectional, in the socio-political, economic, legal order and psychological, developed by agencies and social agents, in a position to prevent or counteract damage, injury or deterioration to women and their social condition. For it, the following dimensions, indicators and values are assumed:

Table 1

Dimensions, indicators and measurement scale

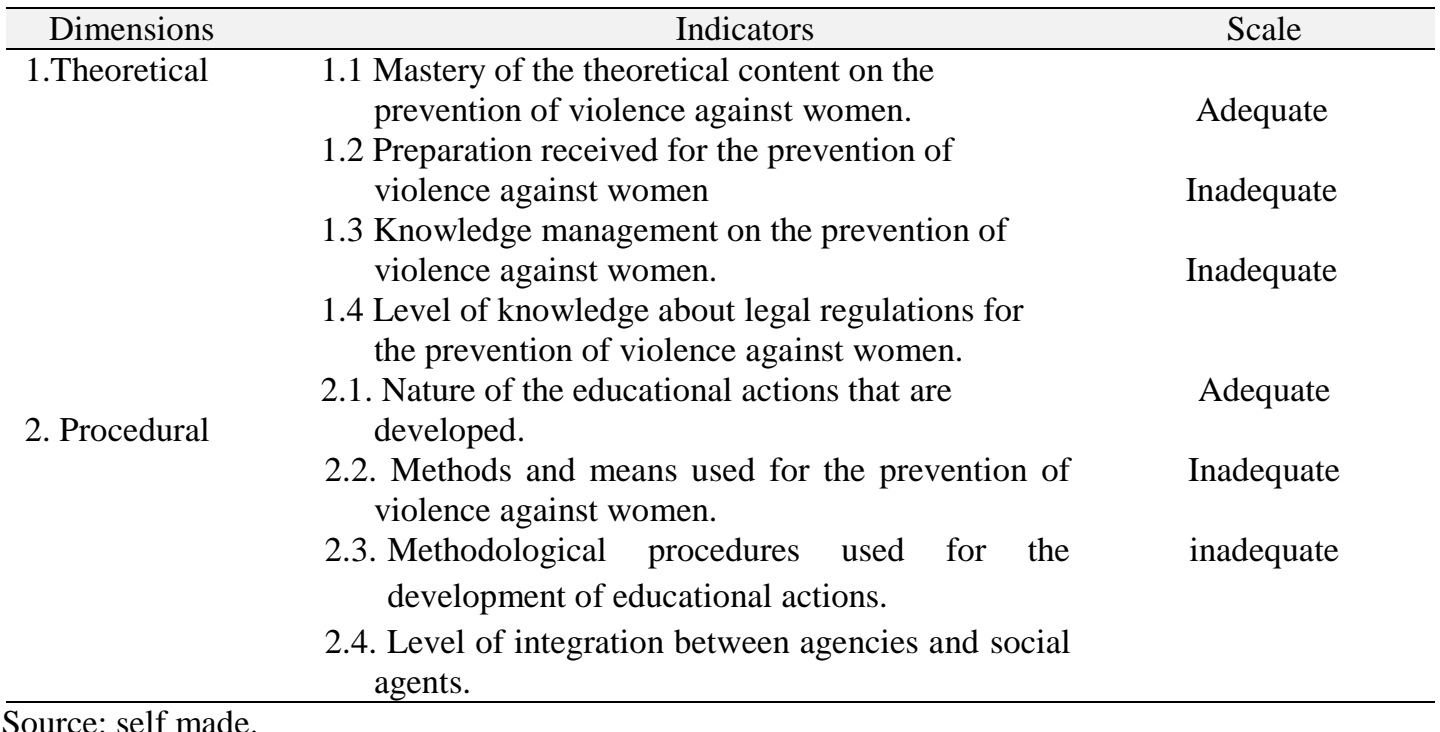

Through the applied instruments and their processing, the characterization of the category studied was obtained from its dimensions and indicators. Of these, the shortcomings and potentialities of the prevention of violence against women stand out (Blanco, 2015; Labarrere \& Valdivia, 2000).

1. The agencies and social agents themselves show the insufficient mastery of the theoretical content they possess. The foregoing is specified in the use, indistinctly, of key terms and definitions to address the issue of gender and, more specifically, violence against women and its prevention. In addition to the lack of knowledge and outdated in relation to research on the subject of prevention of violence against women in contexts and areas of knowledge. In this sense it is limited, insofar as it is limited to the area of knowledge in which they carry out their functions as agencies and social agents. In the same way, it is evident that little information is shared between the agencies and social agents, which hinders the process itself for the practice of preventive actions, is demonstrated by the poor link between them and with it their inability to integrate actions based on greater effectiveness. It is evaluated as inadequate.

Favier, M. R., Manzanares, N. M., Loor, K. M. M., \& Zambrano, T. Y. M. (2021). Management as a necessary tool for the prevention of violence against women. International Research Journal of Management, IT and Social Sciences, 8(6), 679-689. https://doi.org/10.21744/irjmis.v8n6.1979 
2. The training they receive is not directed at the specific issue of preventing violence against women. This lacks planning and systematicity and only in the FMC and the House of Orientation to Women and the Family is it considered a core issue in their work activities. The rest of the agencies and social agents considered in the investigation do not consider them, as these activities do not respond to the institution's training plans as a necessary topic. In relation to the source from which they receive training, it is diverse and responds to the interests of higher levels of the sector to which they belong, so in most cases they are not contextualized to the real needs of the province and the characteristics of the process prevention of violence against women. In the case of the community project "El Garaje", due to its nature as an agency, it recognizes the Oscar Arnulfo Romeu Center and, like the FMC, the university. Evaluated as inadequate.

3. The limited and unsystematic knowledge management of agencies and social agents for the prevention of violence against women is a generality. This is limited to the social role that defines them and their professional profile. For some, such as those with a medical profile, the issue of preventing violence against women is not recognized as one of their priorities, despite considering that their work is oriented to medical care for cases that come in search of medical attention. The management is directed fundamentally to the informative part and not to the educational part of the actions, that is why the facts become repetitive. Evaluated as inadequate.

4. The level of knowledge about legal regulations for the prevention of violence against women is reduced to professionals of the legal sciences, the rest of the agencies and agents have only a notion of matter that does not allow them to have a legal basis for fully advise and guide an individual who requests your help. Such is the case of the House for the guidance of women and families, which does not have professionals of this type on a permanent basis within its work team. Although the importance of this aspect is recognized, there is no preparation to support the orientation actions of each of these agencies and social agents as part of the actions they carry out in order to prevent violence against women. Evaluated as inadequate.

5. Both the agencies and the social agents carry out actions based on the prevention of violence against women, which, in the opinion of the author, are insufficient and lack intentionality with respect to the manifestations of violence against women, that is, they do in a general way. In the same way, the lack of systematicity in the preventive work carried out, as well as the planning and control of its results, is recognized. This work should be aimed at the integration of said agencies and social agents to achieve greater effectiveness of the actions, so that what is established is fulfilled, which in the author's opinion, should reactivate you in order to contextualize each of the actions from the educational point of view. Evaluated as inadequate.

6. The insufficiency of the actions carried out by $100 \%$ of the agencies and social agents is recognized. It is stated that these generally have a unidirectional character, since they are aimed at women, since they are the ones who are generally linked to the educational actions that are carried out. However, in the case of the FMC and the House of Orientation to Women and the Family if they conceive it and the community project "El Garaje", if they conceive the need to include men as involved parties for the prevention of violence against women. In relation to the occurrence of the event, it is evident that the actions they carry out are retroactive, since the educational actions that are carried out are in function of guiding the victim that the event does not happen again and explaining the help resources available to them. your willingness to avoid it. Only $12.8 \%$ acknowledged carrying out educational actions with an anticipatory nature. Evaluated as inadequate.

7. The methods and means used in the same way are limited to the area of knowledge to which it belongs, which provides them with tools that lack educational content and foundations supported from a gender perspective, which is considered essential for their development. It is recognized that these methods and means are not defined, so on many occasions improvisation, creativity and previous experiences are appealed to. In the case of the FMC, the Women's Orientation House recognizes methods and means such as: attention to victims, synthesized in the orientation and the search for concrete solutions in relation to the problems that happen to them. Evaluated as inadequate.

8. In this regard, despite the political will of the State and the work of the agencies and social agents, it has not been possible to centralize a coherent methodological procedure in the Cuban context, especially in the case at hand. The procedure that is followed, in the same way, responds to the social commission and area of knowledge of the agency or agent that performs it, evidencing fissures that require greater activation of the mechanisms already established, to establish the gaps that demonstrate the need to determine a way to make it effective in terms of results. "is recognized as methodological proceduresEverything they do", which is also subject to guidance from higher authorities, demonstrating a lack of need to direct the work of prevention of violence against women from planning, execution and control. Evaluated as inadequate. 
9. The level of integration is almost nil, this is reduced to the alliance agreement according to the needs identified by each of the agencies and social agents. However, the need to join forces and come together to minimize and concentrate work in a contextualized way is recognized. Likewise, the role of the University and especially of the Chair, as an agency for the achievement of this integration, is confessed. Evaluated as inappropriate.

The results obtained demonstrate the need to facilitate ways of interrelation between agencies and social agents that allow the effectiveness of educational actions with the support of the university, it is the motive in the proposal of a product that in the theoretical-practical order contributes remedy deficiencies that affect performance. In this order, the management of the chair of "Guantanamo women, family and society" is considered insufficient in the preparation of agencies and social agents for the prevention of violence against women, so it is proposed to develop a management strategy for the prevention of violence against women (Batista, 2021; Díaz González, 2011).

\section{Results and Discussions}

The central objective of the strategy: to contribute to the systemic and systematic integration of the agencies and social agents for the effectiveness of the prevention of violence against women; from the management of the Chair "Women, family and Guantanamo society, from the scientific-methodological knowledge (Álvarez, 1999; Blanco, 2001). The proposed strategy consists of a set of actions integrated by stages, which allow to give gradual and procedural treatment to the limitations detected in the diagnosis, with the intervention of educational agencies and agents to transform the initial real state to a desired one in the achieving the prevention of violence against women (Krahé, 2018; GarcíaMoreno et al., 2015).

The strategy developed is structured in 4 stages with their respective actions of a coherent, intentional, systemic, transformative and flexible nature. In the assumed dialectical conception, the successive stages must materialize, which have their own teleological character, as shown in figure 1.

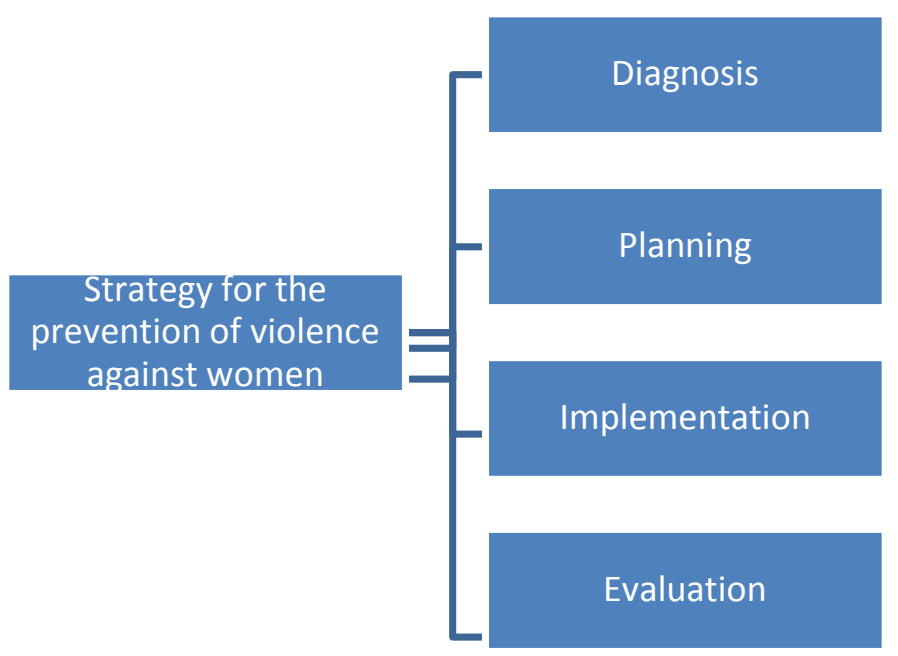

Figure 1. Stages for the prevention of violence against women

1. Diagnostic stage: in The same process of inquiry is carried out that allows to identify the conditions presented by the agencies and social agents for the prevention of violence against women, based on the exploration and taking into account the dimensions and indicators previously specified in the investigation. This stage aims to: determine the weaknesses and potentialities that are recognized by agencies and social agents for the prevention of violence against women and is materialized through the following actions:

a. Determine the real state of preparedness possessed by the agencies and social agents for the prevention of violence against women.

b. Establish the needs and demands of the agencies and social agents to influence the prevention of violence against women.

Favier, M. R., Manzanares, N. M., Loor, K. M. M., \& Zambrano, T. Y. M. (2021). Management as a necessary tool for the prevention of violence against women. International Research Journal of Management, IT and Social Sciences, 8(6), 679-689. https://doi.org/10.21744/irjmis.v8n6.1979 
c. Raise awareness among participants through recognition of manifestations of violence against women.

d. Raise awareness of the need for integration between the chair "Woman, family and Guantanamo society" and the agencies and social agents for the prevention of violence against women.

e. Propose new alternatives for the prevention of violence against women.

2. Planning stage: process of projection and design of actions based on the aspects addressed in the diagnosis. It defines short, medium and long-term objectives that will be achieved from the realization of said actions, in order to achieve the desired state of prevention of violence against women by agencies and social agents. The use of means and tools is determined, which in the procedural order are the responsibility of the Chair "Women, Family and Guantanamo Society", as manager. This stage aims to: reconcile the objectives and tasks to be developed in the socio-educational intervention strategy to achieve the transition from the real state to the desired state of prevention of violence against women. For this, the following actions are proposed:

a. Design of the actions to be developed for the prevention of violence against women through group sessions. Each group work session is made up of three fundamental moments: initial moment, development and closing.

b. Determination of material and human resources to guarantee the development of actions for the prevention of violence against women.

c. Identification of spaces and scenarios for the development of actions for the prevention of violence against women.

d. Design of the work plan to be executed by the Chair "Guantanamo Women, Family and Society" and the agencies and social agents for the prevention of violence against women.

3. Implementation: stagein this stage, the planned actions are executed, according to the established objectives. These are structured as follows: topic, objective, activities, means and evaluation. Its objective is: to implement the actions designed for the prevention of violence against women, for which the following actions are required:

a. Analysis for the approval and forms of implementation of the proposed preventive actions.

b. Implementation of new alternatives for the prevention of violence against women, based on the integration of agencies and social agents and through the development of workshops, film debates and educational talks.

4. Evaluation stage: in it the group returns to the positive and negative aspects of the implemented strategy. It constitutes an analysis of the level of impact and effectiveness on the beneficiaries, contributing to feedback. Different forms of evaluation are proposed (self-evaluation, co-evaluation, hetero evaluation). This stage aims to: assess the feasibility of the proposed actions based on the prevention of violence against women. For this, the following actions were established:

a. Application of instruments and techniques that allow evaluating the feasibility of the actions.

b. Recommendations for a better effectiveness of the proposed actions.

The group work sessions are structured in three fundamental moments: initial moment, development and closing, where objectives, activities, duration, didactic means and evaluation will be established. Next, the procedure of the structure in each of them is explained.

(Stage1) Session No1. Do we work in the team?

Objective: to identify the weaknesses and potentialities of the agencies and social agents for the prevention of violence against women.

Participants: directors of the chair "Guantanamo women, family and society" and members of the agencies and social agents.

Facilitators: the researcher.

Place: Provincial Directorate of the Federation of Cuban Women (FMC)

Means: paleographer to construct "Fishbone Diagram"

Method: joint and explanatory elaboration.

Duration: 1 hour

Initial moment

5. Presentation technique: "While the match lasts". This technique consists of expressing the individual characteristics of each member of the group, as well as the expectations they have about the intervention strategy, while the match is lit. The group contract, the rules of group work, the objectives of the strategy and the expectations of the group are carried out.

6. Development: the fishbone diagram is used ", a resource that allows a graphic diagnosis of the learning needs of the subjects in relation to the basic needs, thus identifying the problem, causes and effects of this and means for its solution. 
Questions for discussion:

How do you rate the work you do to prevent violence against women?

What do you think is necessary to improve your work in the prevention of violence against women?

As agencies and social agents, joint actions are carried out in order to prevent violence against women?

Do you consider the integrated work between agencies, social agents and the chair "Women, family and Guantanamo society" necessary to achieve greater effectiveness in the prevention of violence against women? What ideas or actions do you consider necessary to improve the work you do in terms of preventing violence against women?

The framing of the next sessions is carried out, being established the contract, schedule, number of sessions, as well as the expectations with the program, creating a favorable climate between the facilitator-members that allows the development of the other sessions.

Closing: Express with a word the feelings, ideas or thoughts about the session worked.

Stage 2. Session No.2

Title: Integrate to prevent.

Objective: Promote reflection from the integration of agencies and social agents for the prevention of violence against women.

Participants: members of the chair "Women, family and Guantanamo society", managers and members of the agencies and social agents.

Facilitators: coordinator

Place: Provincial Directorate of the Federation of Cuban Women (FMC).

Media: Computer, data show.

Method: joint and explanatory elaboration.

Duration: 1 hour

Initial moment:

Animation technique: The "Mirror" technique is used, it consists in that the participants divide into pairs, one must act as a mirror and the other do what they do daily in front of the mirror when getting up before go to work, then the roles are reversed.

It is done with the aim of encouraging the group, warming up and putting them on task.

Development:

a. Take up significant aspects of the previous session.

b. Power Point projection, on theoretical and methodological aspects of the integration of agencies and social agents for the prevention of violence against women.

c. Debate- reflective on the material.

Questions:

What theoretical elements do you consider necessary in the integration of agencies and social agents for the prevention of violence against women?

Why is the integration of agencies and social agents necessary for the prevention of violence against women? What avenues are used for the integration of agencies and social agents for the prevention of violence against women?

Closing: "The fan"

A sheet will be taken and each member of the group will write their assessment in relation to the activity and will fold the sheet in such a way that the one who follows does not read what was previously written like this consecutively until a fan is made that later It will be opened by the coordinator and will be read collectively as a summary of the activity.

Session No.3

Title: Generate new ideas!

Objective: Manage social support networks for the prevention of violence against women.

Participants: managers and members of the agencies and social agents.

Facilitators: Coordinator

Place: Provincial Directorate of the Federation of Cuban Women (FMC).

Means: Computer,

Method: joint and explanatory elaboration.

Duration: 1 hour

Favier, M. R., Manzanares, N. M., Loor, K. M. M., \& Zambrano, T. Y. M. (2021). Management as a necessary tool for the prevention of violence against women. International Research Journal of Management, IT and Social Sciences, 8(6), 679-689. https://doi.org/10.21744/irjmis.v8n6.1979 
Opening moment: Using the heating technique: Finish what I say.

Procedure: Participants must end the beginning of the first sentence with a word or other phrase that is related to the said phrase.

Development:

a. Take up aspects of the previous session.

b. Projection of the video "Redes"

c. Debate-reflective on the material.

Questions:

a. How do you value social support for the prevention of violence against women from your work scenario?

b. What is a support network?

c. Do you consider that the support network is necessary?

d. Why does the support network direct the work of agencies and social agents for the prevention of violence against women?

e. How to create a support network for the prevention of violence against women?

f. Who would integrate it? What actions would they take?

The coordinator methodologically explains how the support network would function, as the executor of the integration of agencies and social agents for the prevention of violence against women.

Closing: Use of the gesture technique to express how they felt in the session.

Stage 3. Session No.4

Title: Transform to evolve!

Objective: To implement the support network for the prevention of violence against women.

Participants: managers and members of the agencies and social agents.

Facilitators: Coordinator

Place: Provincial Directorate of the Federation of Cuban Women (FMC).

Media: Conference on the behavior of violence against women in Guantánamo.

Method: joint and explanatory elaboration.

Duration: 1 hour

Initial moment: Use of the heating technique: The magic box.

Procedure: The coordinator puts a small box in the middle of the circle, inside there are several letters that together form the word networks, each member must take a letter and say a word that is related to the letter, that is not communication. For him or those who lose a punishment will be applied.

Development:

a. Take up aspects of the previous session.

b. Conference on the behavior of violence against women in Guantánamo.

c. Debate- reflective on the material.

Questions:

a. How do you assess the current state of violence against women in the province?

b. What do you think about the situation?

c. How to contribute to change this problem from the work they do?

d. What role do networks play in preventing violence against women?

Closing:

The literary resource "Meeting in the Carpentry of the Book La Culpa es de la Vaca" (annex) will be used to assess the role of the unit in achieving the objectives.

This analysis will contribute to the invitation for the next session on the integration of agencies and social agents for the prevention of violence against women.

Sesión No.5

Título: Hacer, haciendo.

Objetivo: Ejecutar acciones para la prevención de la violencia contra la mujer.

Participantes: directivos y miembros de las agencias y agentes sociales.

Facilitadores: Coordinadora

Lugar: Dirección Provincial de la Federación de Mujeres Cubanas (FMC).

Medios: cartulina y plumones.

Método: elaboración conjunta y explicativo.

Duración: 1 hora 
Método: elaboración conjunta y explicativo.

Momento Inicial: Utilización de la técnica de caldeamiento: la pelota caliente.

Procedimiento: Consiste en pasar la pelota dentro de grupo, a la orden de pare por la coordinadora, quien se quede con ella recibe un castigo.

El castigo consiste en proponer vía de realización de una acción para prevenir la violencia contra la mujer.

Desarrollo:

a. Retomar aspectos de la sesión anterior.

b. Realizar una valoración sobre el recurso literario utilizado en la sesión anterior: "Reunión en la Carpintería".

c. Mini-dramatización sobre acciones para la prevención de la violencia contra la mujer.

Procedimiento: la coordinadora dividirá el grupo en cuatro equipos, dos de los equipos tendrán que representar acciones donde se manifiesten la violencia contra la mujer, y los otros dos equipos ejecutarán acciones para su prevención.

Preguntas:

a. Qué elementos se tienen en cuenta para identificar manifestaciones de violencia contra la mujer?

b. Qué elementos se tienen en cuenta para la prevención de manifestaciones de violencia contra la mujer?

c. Qué hacer en caso de que se identifique el empleo de la violencia contra la mujer?

d. Cómo preparar y prepararnos para la prevención de la violencia contra la mujer?

Durante el análisis de las respuestas a las preguntas realizadas, la coordinadora debe explicar los pasos a seguir para la prevención anticipatoria y para la prevención retroactiva, los que podrán consultar en la Guía socioeducativa para la prevención de la violencia contra la mujer, que se propone como aporte práctico de la investigación.

Cierre: La coordinadora brindará a sus participantes la cartulina y plumones para que expongan la materialización de las acciones, para que constituya un referente de trabajo.

Etapa 4. Sesión No.6

Título: Aprendizaje desarrollador.

Objetivo: Valorar los aprendizajes de las agencias y agentes sociales para la prevención de violencia contra la mujer.

Participantes: directivos y miembros de las agencias y agentes sociales.

Facilitadores: Coordinadora

Lugar: Dirección Provincial de la Federación de Mujeres Cubanas (FMC).

Medios:

Método: elaboración conjunta y explicativo.

Duración: 1 hora

Método: elaboración conjunta y explicativo.

Momento Inicial: utilización de la técnica de caldeamiento: Yo deseo...

Procedimiento: cada uno de los participantes debe expresar lo que desea para el futuro en función de la problemática en estudio.

Desarrollo:

a. Retomar aspectos de la sesión anterior.

b. Utilización de la técnica de animación "Las tres sillas".

Procedimiento: se colocan tres sillas en el medio del grupo, donde cada miembro debe sentarse en cada silla y expresar tres cuestiones básicas: Cómo llegué?, Cómo me he sentido en el transcurso de las sesiones?, ¿Cómo me voy?

Preguntas Claves:

a. Qué aprendizajes consideran que obtuvieron en la implementación de las sesiones?

b. Cuánto lograron en las sesiones realizadas? ¿Qué creen qué les falta por lograr?

c. Cómo lo harían?

d. Qué recomendaciones proponen para la prevención de la violencia contra la mujer?

Cierre: Se repartirá una hoja donde los participantes expondrán lo positivo, negativo e interesante de la aplicación de las sesiones.

Favier, M. R., Manzanares, N. M., Loor, K. M. M., \& Zambrano, T. Y. M. (2021). Management as a necessary tool for the prevention of violence against women. International Research Journal of Management, IT and Social Sciences, 8(6), 679-689. https://doi.org/10.21744/irjmis.v8n6.1979 


\section{Conclusion}

The verification of the current status of the category confirmed the existence of inadequacies in the prevention of violence against women based on the poor mastery of the theoretical contents on the subject. With the socioeducational model designed, the aim is to achieve the integration of social agencies and agents for the effectiveness of the prevention of violence against women through the management of the chair "Woman, family and Guantanamo society.

Conflict of interest statement

The authors declared that they have no competing interests.

Statement of authorship

The authors have a responsibility for the conception and design of the study. The authors have approved the final article.

Acknowledgments

We are grateful to two anonymous reviewers for their valuable comments on the earlier version of this paper. 


\section{References}

Álvarez, C. (1999). Didáctica. La escuela en la vida. La Habana: Editorial pueblo y educación, 09.

Batista, G. G. (2021). Compendio de pedagogía. Editorial Pueblo y Educación.

Blanco, A. (2001). Introducción a la Sociología de la Educación: Editorial Pueblo y Educación. La Habana.

Blanco, I. D. (2015). Una metodología de gestión de la cátedra" Manuel Ascunce Domenech" para la formación de intereses profesionales pedagógicos. D-Instituto Central de Ciencias Pedagógicas.

Broadbent, J., \& Laughlin, R. (2009). Performance management systems: A conceptual model. Management Accounting Research, 20(4), 283-295. https://doi.org/10.1016/j.mar.2009.07.004

Díaz González, N. (2011). Estrategia de prevención educativa desde la escuela primaria de zona rural del municipio San Antonio del Sur. La Habana: Universidad de Ciencias Pedagógicas." Enrique José Varona.

Evenson, R. E., \& Westphal, L. E. (1995). Technological change and technology strategy. Handbook of development economics, 3, 2209-2299. https://doi.org/10.1016/S1573-4471(05)80009-9

Fraser, B. J., Walberg, H. J., Welch, W. W., \& Hattie, J. A. (1987). Syntheses of educational productivity research. International journal of educational research, 11(2), 147-252. https://doi.org/10.1016/08830355(87)90035-8

García-Moreno, C., Hegarty, K., d'Oliveira, A. F. L., Koziol-McLain, J., Colombini, M., \& Feder, G. (2015). The health-systems response to violence against women. The Lancet, 385(9977), 1567-1579. https://doi.org/10.1016/S0140-6736(14)61837-7

Horruitiner Silva, P. (2006). Una nueva generación de currículos en la educación superior cubana. Revista de la educación superior, 35(138), 93-112.

Hurlbert, M., \& Gupta, J. (2015). The split ladder of participation: a diagnostic, strategic, and evaluation tool to assess when participation is necessary. Environmental Science \& Policy, 50, 100-113. https://doi.org/10.1016/j.envsci.2015.01.011

Kourilsky, M. L., \& Walstad, W. B. (1998). Entrepreneurship and female youth: Knowledge, attitudes, gender differences, and educational practices. Journal of Business venturing, 13(1), 77-88. https://doi.org/10.1016/S08839026(97)00032-3

Krahé, B. (2018). Violence against women. Current opinion in psychology, 19, 6-10. https://doi.org/10.1016/j.copsyc.2017.03.017

Kultima, K., Sköld, K., \& Borén, M. (2011). Biomarkers of disease and post-mortem changes—heat stabilization, a necessary tool for measurement of protein regulation. Journal of proteomics, 75(1), 145-159. https://doi.org/10.1016/j.jprot.2011.06.009

Labarrere, G., \& Valdivia, G. (2000). Compendio de Pedagogía. La Habana: Pueblo y educación.

Lima, A. (2012). La investigación Pedagógica: otra mirada. Habana: Pueblo e Educación.

Martínez, P., Balderrama, V., Tiscornia, M. D., Figliozzi, G., Linnet, C., Contrera, N., ... \& Rivero, M. G. (2012). Mujeres trabajando en red la violencia de género.

McGill, M. E., Slocum Jr, J. W., \& Lei, D. (1992). Management practices in learning organizations. Organizational dynamics, 21(1), 5-17. https://doi.org/10.1016/0090-2616(92)90082-X

Mujeres, O. (2015). Um marco de apoyo a la prevención de la violência contra la mujer. Nueva York.

Navarrete, D. rodríguez, M., \& Jimenez, O.(2020). Gender Violence on Pandemic of COVID-19. International Journal of Health Sciences, 4(2), 10-18.

Proveyer, C. (2014). Violencia de género. Aproximación desde la realidad cubana. Revista Sexología y Sociedad, 20(1).

Sandberg, W. R., \& Hofer, C. W. (1987). Improving new venture performance: The role of strategy, industry structure, and the entrepreneur. Journal of Business venturing, 2(1), 5-28. https://doi.org/10.1016/0883-9026(87)90016-4

Santisteban, L., \& Egues, A. L. (2014, July). Cultivating adjunct faculty: Strategies beyond orientation. In Nursing Forum (Vol. 49, No. 3, pp. 152-158).

Seethanaik, D. (2015). Stress management in service sector. International ResearchJournal of Management, IT and Social Sciences, 2(11), 1-15. https://sloap.org/journals/index.php/irjmis/article/view/322

Sihabudin, S. (2017). Positioning of futsal management company: a case study. International ResearchJournal of Management, IT and Social Sciences, 4(2), 198-210. https://sloap.org/journals/index.php/irjmis/article/view/952

Toirac Perera, S., Guillarte Ramírez, E., \& Aces Dunand, S. (1998). Las lesiones como forma de violencia en la mujer guantanamera. Sexología y sociedad, 4(9), 15-18.

Favier, M. R., Manzanares, N. M., Loor, K. M. M., \& Zambrano, T. Y. M. (2021). Management as a necessary tool for the prevention of violence against women. International Research Journal of Management, IT and Social Sciences, 8(6), 679-689. https://doi.org/10.21744/irjmis.v8n6.1979 